\title{
METODE DETEKSI CEPAT WHITE SPOT SYNDROME VIRUS (WSSV) DAN INFECTIUOS MYONECROSIS VIRUS (IMNV) MENGGUNAKAN PORTABEL/MOBILE POLYMERASE CHAIN REACTION
}

\author{
Isti Koesharyani") dan Lila Gardenia") \\ 9) Pusat Penelitian Pengembangan Perikanan Budidaya \\ Jl. Ragunan 20, Pasar Minggu, Jakarta Selatan 12540 \\ E-mail: istisugama@yahoo.com \\ "9) Balai Penelitian dan Pengembangan Budidaya Air Tawar \\ Jl. Raya Sempur No. 1, Bogor 16154
}

\begin{abstract}
ABSTRAK
Budidaya udang Penaeus monodon dan Litopenaeus vannamei di Indonesia merupakan komoditas primadona untuk ekspor dan merupakan salah satu spesies unggulan dalam program budidaya pada Kementerian Kelautan dan Perikanan. Kendala pada budidaya udang tersebut adalah penyakit yang disebabkan oleh infeksi virus, terutama white spot syndrome virus (WSSV) dan infectiuos myonecrosis virus (IMNV). Deteksi secara molekuler yang berbasis DNA merupakan metode deteksi sangat akurat dan tepat. Saat ini sudah ada metode deteksi PCR sederhana yang dapat diaplikasi langsung di lapangan, yaitu dengan menggunakan alat Portable-Polymerase Chain Reaction Pockit (iiPCR). Tujuan penelitian ini adalah untuk melakukan deteksi cepat WSSV dan IMNV pada udang $P$. monodon dan $L$. vannamei dengan menggunakan portabel-PCR. Aplikasi deteksi ini diujicobakan pada sampel udang yang diawetkan dan sudah diketahui kondisinya. Hasil analisis memperlihatkan hasil yang sesuai dengan hasil analisis sebelumnya dengan menggunakan PCR konvensional. Metode ini relatif lebih sederhana, cepat (hanya memerlukan waktu kurang dari 90 menit) dan dapat diketahui hasilnya tanpa adanya proses elektroforesis. Metode deteksi ini sangat membantu pembudidaya dalam monitoring penyakit di lapangan secara on the spot, serta cepat dan tepat.
\end{abstract}

KATA KUNCI: ～deteksi cepat, PCR, WSSV, IMNV, Penaeus monodon, dan Litopenaeus vannamei

ABSTRACT: $\quad$ Rapid detection white spot syndrome virus (WSSV) and infectiuos myonecrosis virus (IMNV) by using portable or mobile polymerase chain reaction. By: Isti Koesharyani and Lila Gardenia

Penaeus monodon and Litopenaeus vannamei culture in Indonesia are potential commodities for export, and high ranged species at the Ministry of Maritime Affairs and Fisheries program. Diseases is one constrain or obstacle on the shrimp culture, particularly infected by white spot syndrome virus (WSSV) and infectiuos myonecrosis virus (IMNV). Detection of diseases by DNA molecular-based is very accurate and precise for virus infection. Now, there is simple PCR detection method that can be applied directly in the field, using Portable Pockit-Polymerase Chain Reaction (iiPCR). The purpose of this study was to carry out rapid detection for shrimp viruses WSSV and IMNV infection by using portable PCR. This method was applied on preserved samples of shrimp that is already known of the health status. The test showed consistent results with the previous analysis using conventional PCR. This method was relatively simple, fast only took less than 90 minutes for shrimp health status and without the electrophoresis process as in conventional PCR. This method was very simply, fast and precise and can help for although uneducated farmers in terms for disease monitoring in the field directly.

KEYWORDS: $\quad$ rapid Test, PCR, WSSV, IMNV, Penaeus monodon, and Litopenaeus vannamei

\section{PENDAHULUAN}

Budidaya udang Penaeus monodon dan Litopenaeus vannamei di Indonesia merupakan komoditas ekspor utama yang menjadi spesies unggulan dalam program industrialisasi pada Kementerian Kelautan dan Perikanan. Pada budidaya kedua jenis udang tersebut, infeksi white spot syndrome virus (WSSV) merupakan ancaman yang telah mengakibatkan kerugian yang sangat besar di Asia bahkan di dunia (Huang et al., 1994; Nakano et al., 1994; Koesharyani et al., 2001) dan infectious myonecrosis virus (IMNV) yang merupakan virus baru, yang hanya ada di Indonesia dan Brazil (Senapin et al., 2007). WSSV dan IMNV sampai saat ini masih sering ditemukan dan menginfeksi kedua jenis 
udang tersebut sehingga sering terjadi kegagalan panen yang pada akhirnya menimbulkan kerugian ekonomi yang tidak sedikit bagi para pembudidaya udang.

IMNV merupakan virus yang banyak ditemukan menyerang udang putih $L$. vannamei dan penyakit ini pertama kali ditemukan di Brazil pada tahun 1983 (Briggs et al., 2004 dalam Senapin et al., 2007). Infeksi IMNV merupakan penyakit introduksi yang muncul hampir bersamaan waktunya dengan masuknya udang putih ke Indonesia. Kasus infeksi akibat IMNV pertama kali ditemukan dan menginfeksi udang $L$. vannamei di Situbondo, Jawa Timur pada awal tahun 2006, kemudian menyebar ke sentra-sentra budidaya udang vaname di Indonesia (Senapin et al., 2007; Koesharyani et al., 2012). Serangan IMNV diperkirakan mengakibatkan kerugian ekonomi sebesar \$200 juta di Brazil dan \$200 juta-\$1 miliar di Indonesia (Sunarto, 2011). IMNV merupakan RNA virus utas ganda (doublestranded), termasuk dalam family Totaviridae yang tidak beramplop (non-enveloped), berbentuk icosahedral dengan diameter virion $40 \mathrm{~nm}$ (Senapin et al., 2007). Sampai saat sekarang virus ini masih sering ditemukan pada sentra budidaya udang.

Sedangkan infeksi WSSV yang menjadi kendala utama dalam budidaya udang $P$. monodon ini sudah terjadi sejak tahun 1900-an dan hingga saat ini masih menjadi ancaman serius. Udang yang terinfeksi WSSV dapat mengalami kematian massal beberapa hari setelah terjadinya infeksi (Kasornchandra et al., 1998). Virus ini pertama kali ditemukan di Taiwan pada tahun 1992 (Chou et al., 1995) dan dalam waktu singkat menyebar ke Cina hingga Asia termasuk Indonesia. WSSV dapat cepat tersebar karena penularannya dapat terjadi secara horizontal yaitu dengan mengonsumsi jaringan yang terinfeksi (kanibalisme dan predator) dan melalui air atau water borne infeksi (OIE, 2006).

Diagnosa penyakit atau deteksi kedua jenis virus ini bisa dilakukan dengan beberapa teknik. Metode yang sederhana dapat dilakukan menggunakan teknik histologi dengan pewarnaan H\&E. Metode lain adalah dengan metode molekuler yaitu Polymerase Chain Reaction (PCR) dan Reverse Transcriptase- Polymerase Chain Reaction (RT-PCR) dengan teknik yang lebih cepat dan tepat menggunakan spesifik primer. Selain itu, saat ini telah tersedia beberapa kit komersial yang memudahkan dalam proses pengerjaannya. Teknik terkini lainnya adalah Quantitative PCR (qPCR) ataupun Quantitative RT-PCR (qRT-PCR) yang dapat mendeteksi secara kuantitatif dan sangat akurat di dalam mendeteksi adanya infeksi.

Deteksi secara molekuler merupakan metode deteksi yang sangat sensitif dan spesifik, namun prosedur analisisnya mulai dari ektraksi DNA/RNA, amplifikasi dan elektroforesis harus dikerjakan secara aseptis di dalam laboratorium yang terkontrol dan memerlukan alat laboratorium yang khusus dan rumit. Tetapi dengan berkembangnya metode diagnosa, saat ini telah ada teknik diagnosa berbasis molekuler yang dapat dikerjakan langsung di lapangan "on the spot" menggunakan Pockit (iiPCR) metode ini adalah salah satu teknik deteksi dengan menggunakan portablePCR (Rapid Test on the spot). Teknik ini dapat dengan mudah dikerjakan oleh petani di lapangan (tambak atau hatcheri) dan dapat dikerjakan di luar laboratorium dengan proses amplifikasi yang bersifat semi-kit tanpa proses elektroforesis dan hasil akhir secara kualitatif dapat dilihat langsung pada mesin amplifikasi. Tujuan penelitian ini untuk mengaplikasikan deteksi cepat WSSV dan IMNV pada udang P. monodon dan L. vannamei dengan menggunakan portabel-PCR. Sehingga hasilnya dapat langsung dilihat di lapangan untuk selanjutnya dapat segera diambil tindakan.

\section{BAHAN DAN METODE}

\section{Sampel Udang}

Sampel udang P. monodon berasal dari Sidoarjo, Jawa Timur yang mengalami kematian massal pada tahun 2009 akibat terinfeksi virus yang ditandai dengan spot putih pada permukaan kulit udang. Sedangkan sampel L. vannamei didapat dari tambak udang di Lampung pada tahun 2011 yang juga mengalami kematian massal dengan tanda adanya otot badan yang memutih. Kedua jenis udang tersebut masing-masing disimpan dalam larutan pengawet ethanol 90\% untuk analisis WSSV dan larutan RNAlater ${ }^{\circledR}$ (Qiagen) untuk analisis IMNV yang akan digunakan sebagai bahan uji selanjutnya.

\section{Ekstraksi Asam Nukleat (DNA dan RNA)}

Ekstraksi asam nukleat menggunakan Extraction Kit (IQ PlusTM Extraction Kit) di mana alat untuk ektraksi secara sederhana seperti sentrifugator, mikropiet, dan lain-lain, serta alat amplifikasi sudah tersedia dalam satu paket (Gambar 1). Ekstraksi asam nukleat berupa DNA dan RNA dilakukan dengan teknik spin column secara bersamaan (simultaneous), asam nukleat berupa campuran DNA dan RNA selanjutnya digunakan dalam proses amplifikasi. Sampel organ bisa berupa pleopod (50 mg) atau 10 ekor untuk ukuran PL atau $20 \mathrm{mg}$ hepatopancreas. Sampel dimasukan dalam mikrotube 1,5 mL ditambahkan $500 \mu \mathrm{L}$ larutan-1 (larutan lysis) kemudian dihancurkan dengan pestel. Setelah semua bahan uji lisis atau hancur ditambahkan $500 \mu \mathrm{L}$ larutan-2 (larutan yang mengadung alkohol sebagai pengikat DNA/RNA) dan dicampurkan dengan baik dan diendapkan (spin) selama satu menit untuk memisahkan protein dan asam nukleat. Sebanyak $500 \mu \mathrm{L}$ supernatan yang mengandung asam nukleat (DNA dan RNA) dipindahkan ke dalam spin-column tube, kemudian diendapkan (spin) selama satu menit, lalu cairan yang ada di dalam tabung penampung dibuang, sedangkan asam nukleat berada pada bagian dasar spin column. Untuk pembilasan ditambahkan larutan-2 kembali sebanyak $500 \mu \mathrm{L}$ pada spincolumn, diendapkan selama 3 menit lalu larutan yang 
tertampung pada tabung dibuang. Pindahkan spincolumn (yang mengandung asam nukleat DNA dan RNA) pada $1,5 \mathrm{~mL}$ tabung mikro baru dan tambahkan pelarut/elution asam nukleat sebanyak $200 \mu \mathrm{L}$ (untuk sampel jaringan) dan $400 \mu \mathrm{L}$ (untuk sampel hepatopankreas) kemudian diendapkan (spin) selama satu menit. Selanjutnya asam nukleat (DNA dan RNA) yang didapat, digunakan untuk amplifikasi WSSV dan IMNV. Untuk jumlah sampel tersebut di atas akan menghasilkan konsentrasi DNA/RNA 10-100 ng/ $\mu \mathrm{L}$.

\section{Amplifikasi}

WSSV dan IMNV diamplifikasi menggunakan IQ PlusTM WSSV Kit dan IQ PlusTM IMNV Kit. Sebelumnya persiapkan Premix pack (dalam mikrotube) yang mengandung (dNTPs, spesifik primer WSSV dan atau IMNV, flourescent probes dan enzim) dalam bentuk pelet kering kemudian ditambahkan $50 \mu \mathrm{L}$ premix buffer sebagai pelarut premix (larutan yang telah dilarutkan harus segera digunakan dalam waktu kurang dari satu jam) dan dilanjutkan pada proses berikutnya. Ambil atau tambahkan 1 loop (loop plastik tersedia dalam kit) asam nukleat DNA/RNA uji ke dalam larutan premix (Gambar. 2A). Selanjutnya semua premix dan DNA/RNA uji dipindahkan ke dalam R-tube (Gambar 2B dan 2C), kemudian R-tube diletakkan pada holder (Gambar 2D) yang telah tersedia dengan posisi baik dan benar dengan menggunakan sarung tangan, karena bagian bawah R-tube berupa tabung gelas optikal yang berpengaruh dalam proses deteksi/membaca dengan bantuan flourescent. Bagian atas R-tube diberi label kemudian setelah tertutup dengan baik, rangkaian R-tube dimasukkan ke dalam mesin Pockit. Pada alat dipilih panjang gelombang $520 \mathrm{~nm}+550 \mathrm{~nm}$, selanjutnya mesin dijalankan dengan menekan tombol "Run" sesuai dengan petunjuk.
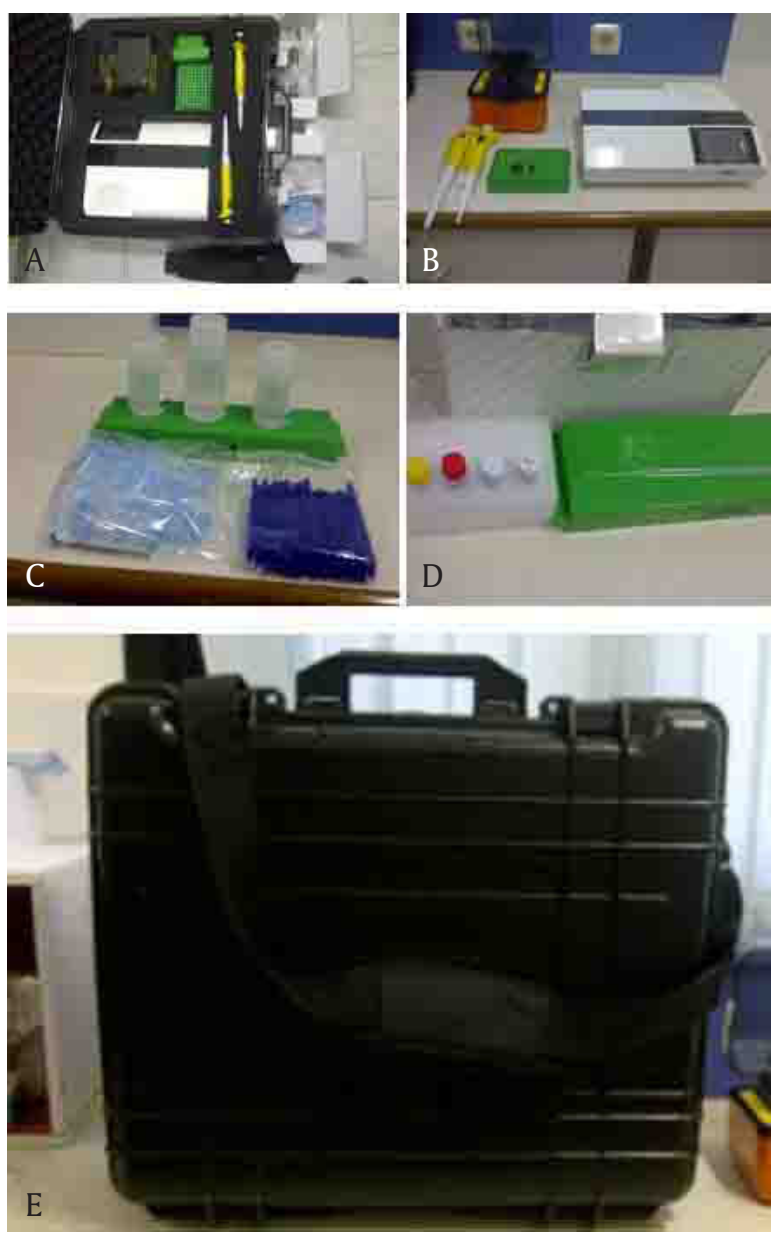

Gambar 1. Perlengkapan Pockit Nucleic Acid Analyzer portabel-PCR berupa mesin PCR, mikro pipet dan alat spind down (A \& B), serta paket reagensia ekstraksi dan amplifikasi (C \& D) yang dikemas dalam satu koper kecil yang siap dibawa untuk pengecekan virus udang di lapangan (E)

Figure 1. Pockit Nucleic Acid Analyzer for portable-PCR, micro pipet and spind down (A \& B), extract reagent and amplification ( $C \& D$ ) package in one case ready for checking virus $(E)$ 

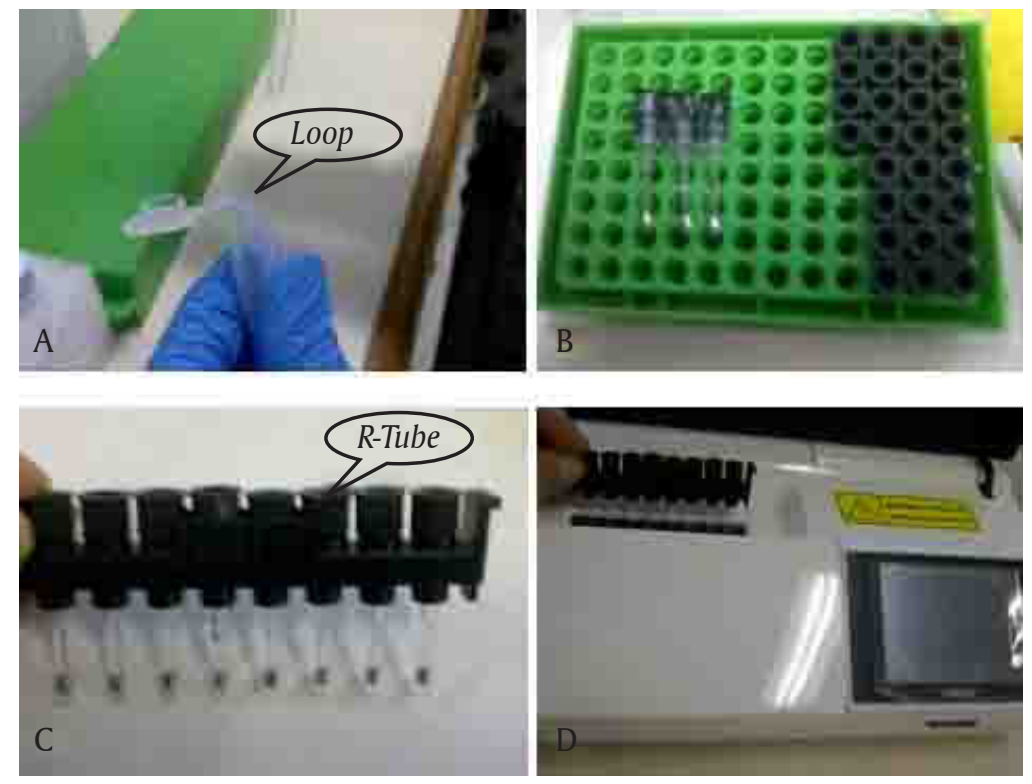

Gambar 2. Tahap amplifikasi pada portabel-PCR menggunakan loop untuk mengambil template DNA/RNA sebesar 1 mikroliter (A), dipindahkan ke dalam R-tube/tabung $\mathrm{R}$ amplifikasi (B), ditempatkan pada holder dan ditutup dengan baik (C), selanjutnya posisi tabung pada holder dimasukan pada alat PCR

Figure 2. Amplification phase at portable-PCR use loop for DNA/RNA 1 microliter template (A), R-tube amplification (B), place at closed holder (C), and position tube placing at PCR

\section{HASIL DAN BAHASAN}

Keberhasilan budidaya udang ditentukan oleh kualitas induk dan benih, deteksi dini adanya penyakit dan skrining induk dan benur sebelum tebar adalah hal yang sangat penting dan harus dilakukan. Hanya induk sehat bebas virus yang dapat menghasilkan benur yang berkualitas dan lebih tahan penyakit. Menurut Sritunyalucksana et al. (2006), metode yang paling efektif mencegah kerugian akibat penyakit pada udang adalah dengan mencegah masuknya patogen ke dalam sistem budidaya. Pengawasan ketat pada prosedur-prosedur tersebut (deteksi dini, skrining induk, dan benur sebelum tebar), serta ditambah pencegahan masuknya hewan yang menjadi "natural carrier" terbukti dapat mengurangi tingkat infeksi WSSV seperti yang berhasil dilakukan di Jepang.

Saat ini, metode deteksi dini dan skrining induk, serta benih yang banyak digunakan adalah Polymerase Chain Reaction/PCR (Lo et al., 1998). Metode berbasis molekuler ini menjadi pilihan karena sangat sensitif dan spesifik untuk mendeteksi virus penyebab penyakit pada udang. Kelebihan lain dari metode ini yaitu dapat menghasilkan amplifikasi/perbanyakan produk target yang akurat, cepat, dan spesifik, serta hanya membutuhkan jumlah sampel yang sedikit. Namun metode ini juga memiliki kekurangan antara lain mudah terkontaminasi. Selain itu, dikarenakan memerlukan berbagai macam alat dengan ukuran yang cukup besar, maka sebagian besar tahap analisis sampel harus dilakukan di dalam laboratorium.

Pockit Nucleic Acid Analyzer adalah salah satu teknik deteksi dengan menggunakan portable-PCR (Gambar 1) yang dapat melakukan analisis secara langsung di lapangan (Rapid Test on the spot). Seluruh perlengkapan yang diperlukan sudah siap dalam satu koper kecil sehingga mudah dibawa kemana saja.

Setelah proses amplifikasi (Gambar 2) pada mesin Pockit Nucleic Acid Analyzer, sampel langsung dianalisis dan hasilnya dapat dilihat pada layar mesin. Hasil analisis dapat diperoleh dalam waktu yang lebih singkat (sekitar satu jam saja). Proses analisis sampel dapat menjadi lebih cepat karena tidak memerlukan proses elektroforesis. Dengan demikian kontaminasi akibat percikan aerosol hasil buka/tutup mikrotube (yang telah mengandung banyak DNA hasil amplifikasi) dapat dihindari.

Hasil analisis WSSV dan IMNV menggunakan portabel-PCR sesuai dengan hasil analisis kedua virus tersebut sebelumnya menggunakan PCR konvensional 
Tabel 1. Sampel udang dan hasil analisis WSSV dan IMNV menggunakan PCR konvensional dan portabel-PCR

Table 1. Result of WSSV and IMNV analyzed with PCR conventional and portable-PCR

\begin{tabular}{|c|c|c|c|c|}
\hline \multirow{2}{*}{$\begin{array}{l}\text { Spesies } \\
\text { Species }\end{array}$} & \multicolumn{2}{|c|}{$\begin{array}{l}\text { PCR konvensional } \\
\text { Conventional PCR }\end{array}$} & \multicolumn{2}{|c|}{$\begin{array}{l}\text { Portabel-PCR } \\
\text { Portable-PCR }\end{array}$} \\
\hline & WSSV & IMNV & WSSV & IMNV \\
\hline L. vannamei-1 & Negatif (Negative) & Positif (Positive) & Negatif (Negative) & Positif (Positive) \\
\hline L. vannamei-2 & Negatif (Negative) & Positif (Positive) & Negatif (Negative) & Positif (Positive) \\
\hline L. vannamei-3 & Negatif (Negative) & Negatif (Negative) & Negatif (Negative) & Negatif (Negative) \\
\hline P. monodon -1 & Positif (Positive) & Negatif (Negative) & Positif (Positive) & Negatif (Negative) \\
\hline P. monodon -2 & Positif (Positive) & Negatif (Negative) & Positif (Positive) & Negatif (Negative) \\
\hline P. monodon -3 & Negatif (Negative) & Negatif (Negative) & Negatif (Negative) & Negatif (Negative) \\
\hline
\end{tabular}

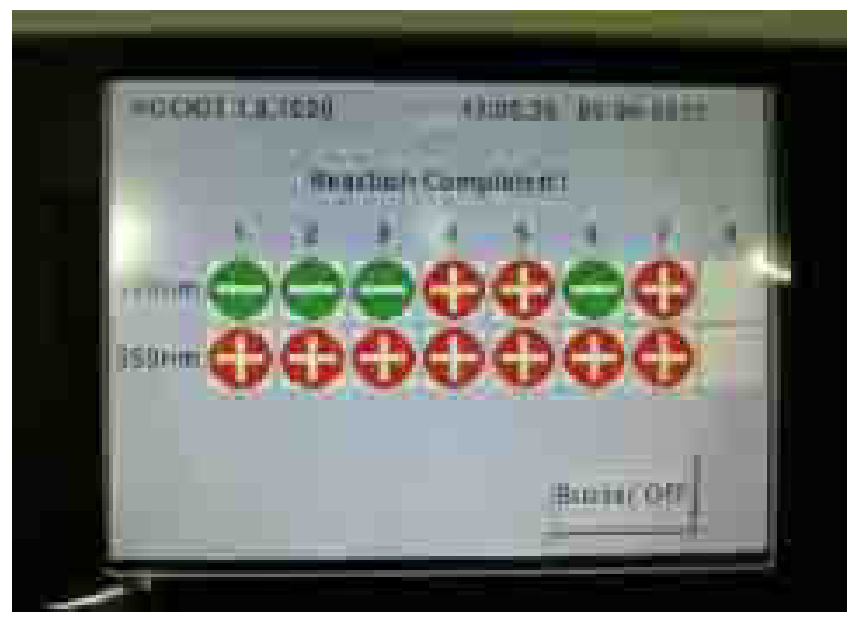

Gambar 3. Hasil analisis WSSV pada sampel udang L. vannamei (sampel 1-3 baris atas) dan P. monodon (sampel 4-6 baris atas) dengan menggunakan portabel-PCR. Sampel 7 baris atas merupakan plasmid positif kontrol WSSV. Sedangkan baris bawah menunjukkan internal kontrol

Figure 3. Result of WSSV analysis on shrimp samples L. vannamei (samples 1-3 top line) and P. monodon (samples 4-6 top line) by using PCR-portable. Sample 7 on top line indicates positive plasmid for WSSV control, while bottom line indicates control internal

(Tabel 1). Walaupun sampel jaringan yang digunakan sudah cukup lama disimpan ( $>1$ tahun) namun terlihat kualitas DNA dan RNA hasil ekstraksi masih sangat baik. Hal ini disebabkan karena penyimpanan jaringan udang dalam larutan preservasi ethanol $90 \%$ untuk sampel DNA dan RNA-later untuk sampel RNA. Penyimpanan sampel pada larutan yang tepat sangat memengaruhi kualitas DNA/RNA yang dihasilkan, di mana RNA later dapat menjaga kestabilan RNA dalam jaringan hingga satu tahun penyimpanan (Novita et al., 2009). Selain itu, metode Extraction Kit (IQ PlusTM Extraction Kit) dengan teknik spin column menghasilkan asam nukleat DNA dan RNA yang lebih bersih dan berkualitas tinggi. Dengan demikian kemungkinan terjadinya "false negatif" akibat kualitas DNA/RNA yang buruk dapat dihindari. Teknik ekstraksi pada kit ini dapat mengekstraksi DNA dan RNA secara bersamaan sehingga menghemat waktu dan hasil analisis dapat lebih cepat diperoleh.

Analisis menggunakan PCR konvensional, untuk pencegahan terjadinya false negatif dilakukan melalui pengecekan kualitas DNA/RNA hasil ekstraksi sampel udang menggunakan primer set (143F dan 145R). Pengecekan tersebut dilakukan sebelum DNA/RNA sampel tadi diamplifikasi menggunakan primer spesifik untuk virus yang diduga menginfeksi udang tersebut. Pasangan primer $143 \mathrm{~F}$ dan $145 \mathrm{R}$ ini merupakan bagian urutan 18S rRNA dari decapod (Lo et al., 1996) yang akan mengamplifikasi gen decapod sehingga menjadi indikator baik/tidaknya kualitas DNA/RNA hasil ekstraksi (internal kontrol).

Pengujian menggunakan Pockit Nucleic Acid Analyzer 


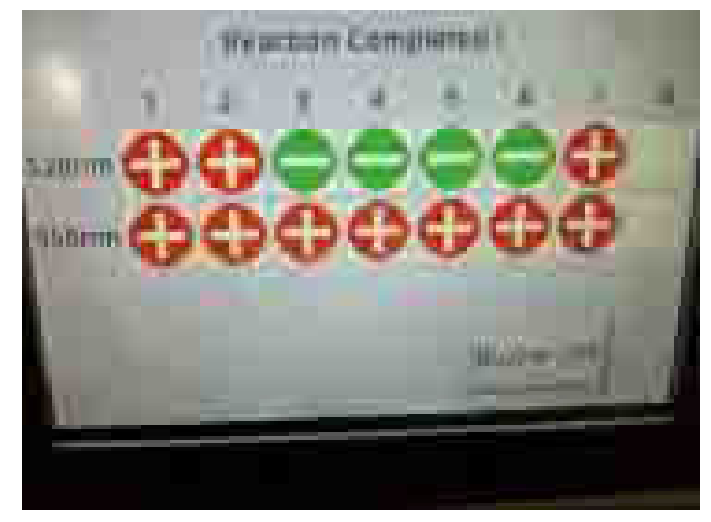

Gambar 4. Hasil analisis IMNV pada sampel udang L. vannamei (sampel 1-3 baris atas) dan P. monodon (sampel 4-6 baris atas) dengan menggunakan portabel-PCR. Sampel 7 baris atas merupakan plasmid positif kontrol WSSV. Sedangkan baris bawah menunjukkan internal kontrol

Figure 4. Result of IMNV analysis on shrimp samples L. vannamei (samples 1-3 top line) and P. monodon (samples 4-6 top line) by using PCR-portable. Sample 7 on top line indicates positive plasmid for WSSV control, while bottom line indicates control internal

pada mobile-PCR ini berdasarkan pada prinsip multiplex iiPCR untuk mendeteksi virus pada udang. Penambahan primer spesifik dan probe hidrolisis berfluorescent digunakan untuk menghasilkan sinyal yang akan berpendar pada saat berikatan dengan DNA virus yang terdapat pada sampel. Primer dan probe tersebut akan berikatan dengan virus target (pada urutan asam nukleat tertentu), namun tidak akan bereaksi dengan DNA genom udang dan asam nukleat dari patogen lain. Primer dan probe untuk internal kontrol akan berikatan dengan gen "house keeping" dari udang (IQ+ user manual, 2012).

Analisis dengan Pockit Nucleic Acid Analyzer portabelPCR tidak memerlukan tahapan sebelum amplifikasi untuk pengecekkan DNA/RNA hasil ekstraksi. Selain itu, kondisi sampel dan kualitas DNA/RNA hasil ekstraksi yang telah dilakukan dapat sekaligus langsung terllihat secara kualitatif pada mesin. Bagian atas merupakan hasil pengukuran pada panjang gelombang $520 \mathrm{~nm}$ yang menunjukan hasil analisis deteksi adanya infeksi virus, sedangkan pada bagian bawah merupakan hasil pengukuran pada panjang gelombang $550 \mathrm{~nm}$ yang menunjukkan kualitas DNA/RNA yang diekstrak sebagai internal kontrol untuk bahan pengujian analisis deteksi (Gambar 3 dan 4). DNA/RNA yang baik harus menunjukkan tanda positif (+). Sebaliknya, bila kualitas DNA/RNA tidak baik, maka akan menunjukan tanda negatif (-) yang berarti harus melakukan tahapan ekstraksi ulang DNA/RNA. Indikator tersebut dengan mudah terbaca pada layar mesin portabelPCR dan menjadi sangat penting untuk mengurangi kemungkinan kesalahan analisis akibat "false negatif" yang disebabkan kualitas DNA/RNA yang kurang baik.

\section{KESIMPULAN}

Deteksi cepat menggunakan portabel-PCR ini sederhana, cepat dan dapat diketahui hasilnya tanpa adanya proses elektroforesis. Interpretasi hasil sangat mudah dapat dilihat secara langsung pada layar di Mesin PCR dengan tanda positif dan negatif yang jelas, adanya internal kontrol DNA/RNA yang menunjukkan kualitas DNA/RNA yang diekstraksi mengurangi kemungkinan terjadinya "false negatif" pada hasil analisis sampel. Penggunaan portabel-PCR sangat membantu pembudidaya dalam monitoring penyakit di lapangan secara cepat dan tepat tanpa menggunakan fasilitas laboratorium.

\section{DAFTAR ACUAN}

Chou, H.Y., Huang, C.Y., Wang, C.H., Chiang, H.C., \& Lo, C.F. (1995). Pathogenicity of baculovirus infection causing white-spot syndrome in cultured penaeid shrimp in Taiwan. Diseases of Aquatic Organisms, 23, 165-173.

Huang, J., Song, S.L., Yu, J., \& Yang, C.H. (1994). Baculoviral hypodermal and hematopoietic necrosis-patholgy of the shrimp explosive epidemic disease. Yellow Sea Fishery Research Institute, Qingdao, PR, China (Abstract).

IQ Plus ${ }^{\mathrm{TM}}$ WSSV Kit for White Spot Syndrome Virus Detection. (2012). User Manual.

Kasornchandra, J., Boonyaratpalin, S., \& Itami, T. (1998). Detection of white-spot syndrome in cultured penaeid shrimp in Asia: Microscopic observation and polymerase chain reaction. Aquaculture, 164, 243-251. 
Koesharyani, I., Gardenia, L., \& Supriyadi, H. (2012). Multi infeksi pada udang Litopenaeus vannamei: Diagnosis dengan Polymerase Chain Reaction (PCR) dan Reverse Transcriptase-Polymerase Chain Reaction (RT-PCR). J. Ris. Akuakultur, 7(1), 73-84.

Koesharyani, I., Roza, D., Mahardika, K., Johnny, F., Zafran, \& Yuasa, K. (2001). Manual for fish disease diagnosis-II (Marine fish and Crustacean diseases in Indonesia). Gondol Research Institute for Mariculture and Japan International Cooperation Agency. 49 p.

Nakano, H., Koube, H., Umezawa, S., Momoyama, K., Hiraoka, M., Inouye, K., \& Oseko, N. (1994). Mass mortalities of cultured kuruma shrimp, Penaeus japonicus, in Japan in 1993: epizootiological survey and infecion trails. Fish Pathol., 29, 135-139.

Lo, C.F., Leu, J.H., Ho, C.H., Chen, C.H., Peng, S.E., Chen, Y.T., Chou, C.M., Yeh, P.Y., Huang, C.J., \& Kou, G.H. (1996). Detection of bacolovirus associated with white spot syndrome (WSBV) in penaeid shrimps unsing polymerase chain reaction. Diseases of Aquatic Organisms, 25, 133-141.

Lo, C.F., Chang, Y.S., Cheng, C.T., \& Kou, G.H. (1998). PCR monitoring of cultured shrimp for white spot syndrome virus (WSSV) infection in growout ponds. In Flegel, T.W. (Ed.). Advances in shrimp biotechnology.
National Center for Genetic Engineering and Biotechnology, Bangkok.

Novita, H., Mufidah, T., \& Koesharyani, I. (2009). Perbandingan penggunaan berbagai preservasi RNA jaringan dengan RNAlater, alkohol dan alkoholgliserol untuk deteksi IMNV dengan PCR. J. Ris. Akuakultur, 4(3), 377-383

OIE. (2006). Manual of diagnostic test for aquatic animals. Fifth ed. OIE, Paris. (http://www.oie.int/ eng/normes/fmanual).

Senapin, S., Phewsaiya, K., Briggs, M., \& Flegel, T.W. (2007). Outbreaks of infectious myonecrosis virus (IMNV) in Indonesia confirmed by genome sequencing and use of an alternative RT-PCR detection method. Aquaculture, 266, 32-38.

Sritunyalucksana, K., Srisala, J., McColl, K., Nielsen, L., \& Flegel, T.W. (2006). Comparison testing methods for white spot syndrome virus (WSSV) infections in penaeid shrimp. Aquaculture, 255, 95-104.

Sunarto, A. (2011). Current status and problems of infectious myonecrosis virus (IMNV) in Pacific white shrimp (Litopenaeus vannamei) in Indonesia. Paper presented in "One Day Workshop on Prevention and Control of IMNV in Indonesia", Jakarta, 14 July 2011. Ministry of Marine Affairs and Fisheries. Jakarta, 6 pp. 
